adverse events (headaches $\mathrm{n}=8$, nausea $\mathrm{n}=2$, abdominal pain $\mathrm{n}=2$, chest pain $\mathrm{n}=1$, chills $\mathrm{n}=2$, dyspnea $\mathrm{n}=3$, myalgias $\mathrm{n}=3$, pruritis $\mathrm{n}=4$, fatigue $\mathrm{n}=3$, and rash $\mathrm{n}=5$ ).

\begin{tabular}{llllll}
\multicolumn{5}{l}{ Abstract FRI0009 Table 1} \\
\hline & HAQ & $\begin{array}{l}\text { Stiffness } \\
\text { (minutes) }\end{array}$ & $\begin{array}{l}\text { Pain (VAS- } \\
\text { cm) }\end{array}$ & $\begin{array}{l}\text { Swollen joint } \\
\text { count }\end{array}$ & $\begin{array}{l}\text { Tender joint } \\
\text { count }\end{array}$ \\
\hline Baseline & $1.95 \pm$ & $92 \pm 88$ & $6.4 \pm 2.5$ & $13.21 \pm 11$ & $13.7 \pm 11.8$ \\
& 0.6 & & & & \\
6 & $1.22 \pm$ & $56 \pm 75$ & $4.9 \pm 3.0$ & $11.5 \pm 10.9$ & $10.5 \pm 10.2$ \\
months & 0.7 & & & & \\
p value & 0.0002 & 0.13 & 0.07 & 0.29 & 0.07 \\
\hline
\end{tabular}

Conclusion Infliximab is often used in more difficult RA patients (older, long-standing RA, multiple DMARD failures). This referral pattern may explain the increased incidence of adverse events and suboptimal clinical response noted in our cohort. However, our results suggest a trend towards rapid, clinically important improvement in measures of disease activity. Ongoing follow-up of this growing group of patients will provide necessary information regarding the appropriate role of infliximab in the treatment of RA.

\section{FRI0010 EFFECT OF OSTEOPROTEGERIN AND PAMIDRONATE TREATMENT IN TRANSGENIC MICE OVEREXPRESSING HUMAN TNF-ALPHA}

${ }^{1} \mathrm{~K}$ Redlich, ${ }^{2} \mathrm{~A}$ Maier, ${ }^{1} \mathrm{~S}$ Hayer, ${ }^{3} \mathrm{G}$ Kollias, ${ }^{4} \mathrm{CR}$ Dunstan, ${ }^{5} \mathrm{~S}$ Lang, ${ }^{6} \mathrm{~W}$ Woloszczuk, ${ }^{1} \mathrm{G}$ Steiner, 'I Smolen, 'G Schett. 'Internal Medicine III, Division of Rheumatology; ${ }^{2}$ Department of Radiology; ${ }^{3}$ Department. of Molecular Genetics, Hellenic Pasteur Institute, Athens, Greece; ${ }^{4}$ Department of Pathology, Amgen, Inc., California, USA; ${ }^{5}$ Department of Pathology; ${ }^{6}$ Ludwig Boltzmann-Institute of Exp. Endocrinology, University of Vienna, Vienna, Austria

10.1136/annrheumdis-2001.1139

Background Rheumatoid arthritis (RA) is characterised by progressive joint destruction resulting from chronic inflammation. Recent studies suggest that bone-resorbing osteoclasts formed in the synovium play an important role in bone destruction in RA. Objectives We studied the effect of anti-resorptive treatment with osteoprotegerin and/or pamidronate compared to TNF blockade with infliximab on the development of erosions in TNF overexpressing mice.

Methods Systemic treatment with osteoprotegerin (OPG), pamidronate, both osteoprotegerin and pamidronate, infliximab or phosphate buffered saline (PBS) was carried out by intravenous injection. Treatment was initiated at the time of onset of arthritis and continued over $35 \mathrm{~d}$. Clinical, serological, radiological and histological outcomes were assessed after treatment.

Results Clinical improvement, as assessed by reduction in paw swelling was only seen in the infliximab treated group. X-Rays of the hind paws were performed to quantify erosive changes. Erosions were detectable in each joint compartment Grading of erosions was performed analogous to the Larsen score. There was a marked and significant $(\mathrm{p}<0.05)$ reduction in the Larsen scores of mice treated with OPG (-54\%), OPG and pamidronate $(-64 \%)$ and infliximab (-66\%). Microscopic examination of decalcified joint tissue sections using a semiquantitative method, revealed a significant $(\mathrm{p}<0.05)$ reduction in the extent of erosions in all treatment groups (OPG: $-56 \%$; pamidronate: $-53 \%$;
OPG + pamidronate: $-81 \%$; infliximab ?46\%) when compared to controls.

Conclusion These data suggest that anti-resorptive treatment may have a significant potential in TNF-mediated bone destruction.

\section{FRI0011 THE EFFECT OF STEROID INJECTION AFTER ARTHROSCOPIC SYNOVECTOMY IN RHEUMATOID KNEE SYNOVITIS}

SI Kuzmanova, PC Solakov, AN Atanasov, SA Andreev, K Klinkanov. Rheumatology, Medical Faculty Hospital, Plovdiv, Bulgaria

\subsection{6/annrheumdis-2001.1140}

Background The study assesses the therapeutic result from a single application of local corticosteroid (betamethasone $7 \mathrm{mg}$ ) seven days after the performance of an arthroscopic synovectomy of the knee joint in patients with rheumatoid arthritis (RA).

Objectives An arthroscopic shaver-synovectomy with a consecutive tidal lavage with $4-5 \mathrm{~L}$ saline was performed in $73 \mathrm{RA}$ patients $(51 \mathrm{~F} / 22 \mathrm{M})$ with mean disease duration $4,5( \pm 1.8)$ years and active synovitis of the knee joints. In 23 patient $(15 \mathrm{~F} / 8 \mathrm{M})$ after the arthroscopic synovectomy (AS) an application of a local corticosteroid was not performed (control group).

Methods The assessment of the results was done on 1st, 3rd and on 6th month after AS according to the Knee Society Rating System, using a scale for assessment of the knee joint in respect of the changes of the pain, range of motion (ROM), joint stability and some functional parameters.

Results A higher degree of reducing of the pain, improvement in the joint stability of the gait and of the ability of climbing and descending scales in all patients with local application of corticosteroid after AS was found compared to controls $(\mathrm{p}<0.001)$

Conclusion The results confirm the better effect from the administration of a local corticosteroid one week after an arthroscopic synovectomy in rheumatoid knee synovitis.

\section{REFERENCES}

1 Sharma A, Baethge BA, Acebes JC, et al. Arthroscopic lavage treatment in rheumatoid arthritis of the knee. J Rheumatol. 1996;23(11):1872-4

2 Srinivasan $A$, Amos $M$, Webley $M$. The effect of joint washout of steroid injection compared with either joint washout of steroid injection alone in rheumatoid knee effusion. Br J Rheumatol. 1995;1:219-27

\section{FRI0012 ADVERSE EVENTS, DRUG WITHDRAWAL AND EFFICACY OF LEFLUNOMIDE IN UNSELECTED OUTPATIENTS WITH RHEUMATOID ARTHRITIS}

${ }^{1} \mathrm{~L}$ Mourad, ${ }^{1} \mathrm{EN}$ van Roon, ${ }^{2} \mathrm{TL}$ Jansen, ${ }^{2} \mathrm{PM}$ Houtman, ${ }^{2} \mathrm{GA}$ Bruyn, ${ }^{2} \mathrm{EN}$ Griep, ${ }^{1}$ WA Baars, ${ }^{3} \mathrm{JR}$ Brouwers. 'Department Clinical Pharmacy; ${ }^{2}$ Department Rheumatology, Medisch Centrum Leeuwarden, Leeuwarden; ${ }^{3}$ Department of Social Pharmacy and Pharmacoepidemiology, State University of Groningen, Groningen, The Netherlands

\subsection{6/annrheumdis-2001.1141}

\section{Background}

Objectives Leflunomide (LEF) is a disease modifying antirheumatic prodrug with immunomodulating, antiproliferative and antiinflammatory properties. We studied our first daily practice experience with LEF in the Outpatient Department of Rheumatology.

Methods In this prospective study we included all consecutive patients with active rheumatoid arthritis (RA), starting treatment 